\title{
Historical analysis of the records of sylvan yellow fever in the State of Amazonas, Brazil, from 1996 to 2009
}

\author{
Maria das Graças Gomes Saraiva ${ }^{[1],[2], ~ R a u l ~ D i n i z ~ S o u z a ~ A m o r i m ~}{ }^{[1]}$, \\ Marco Antônio Sabóia Moura ${ }^{[1]}$, Eyde Cristianne Saraiva dos Santos ${ }^{[3]}$, \\ Leônidas Sales Sampaio ${ }^{[4],}$ Maria das Graças Vale Barbosa ${ }^{[1],[2],[5]}$ \\ and Samira Bührer-Sékula ${ }^{[1],[6]}$
}

\begin{abstract}
[1]. Departamento de Epidemiologia e Saúde Pública, Fundação de Medicina Tropical “Doutor Heitor Vieira Dourado", Manaus, AM. [2]. Faculdade de Medicina, Universidade Nilton Lins, Manaus, AM. [3]. Departamento de Engenharia Agricola e Solos, Faculdade de Ciências Agrárias, Universidade Federal do Amazonas, Manaus, AM. [4]. Gerência de Vigilância de Doenças Transmissíveis no Amazonas, Fundação de Vigilância em Saúde, Manaus, AM. [5]. Escola Superior de Ciências da Saúde, Programa de Pós-Graduação de Medicina Tropical, Universidade do Estado do Amazonas, Manaus, AM. [6]. Instituto de Patologia Tropical e Saúde Pública, Universidade Federal de Goiás, Goiânia, GO.
\end{abstract}

\begin{abstract}
Introduction: Yellow fever is a non-contagious infectious disease, highly lethal, transmitted by the Aedes, Haemagogus and Sabethes. Methods: Descriptive retrospective study of the yellow fever cases in Amazonas, between 1996 and 2009. Results: Forty two cases of yellow fever were confirmed, with 30 deaths, $10 \%$ of which were foreigners. Conclusions: The presence of Aedes aegypti and Aedes albopictus in both rural Amazonas and its capital demonstrates the dispersion of these vectors and underscores the need for better and continuous epidemiological and entomological control.
\end{abstract}

Keywords: Epidemiological aspects. Spatial analysis. Vaccine.

Yellow fever is a non-contagious infectious disease, highly lethal disease of acute and short duration fever, whose etiological agent is a virus that belongs to the genus Flavivirus, family Flaviviridae ${ }^{1-3}$. A specific diagnosis is done through isolation and viral identification, detecting either viral antigens or nucleic acids, histopathological diagnosis (post-mortem specimens), and the serological complements pertaining to the viral identification ${ }^{3,4}$. The disease is transmitted to humans by the bite of infected mosquitoes of the genus Haemagogus, Sabethes, and Aedes ${ }^{5,6}$.

In the Amazon, the source of infection of this disease is related to non-human primates, of which the principal hosts are the monkeys of the genus Cebus (tufted capuchin), Alouatta (brown howler), Ateles (spider monkey) and Callithrix (tamarin) $)^{4}$.

Brazil presents the largest endemic area in the wild form, covering the basins of the rivers Amazonas, Araguaia-Tocantins and Paraná . Between 1989 and 2008, 546 cases of yellow fever were registered in Brazil, responsible for 241 deaths, the highest registry being in the year 2000 (85 cases), all of which occurred in risk areas of the States: Acre, Amazonas, Pará, Roraima, Rondônia, Mato Grosso, Mato Grosso do Sul,

Address to: Dra. Maria das Graças Gomes Saraiva. Depto. de Epidemiologia e Saúde Pública/Fundação de Medicina Tropical "Doutor Heitor Vieira Dourado". Av. Pedro Teixeira 25, Dom Pedro, 69040-000 Manaus, AM, Brasil.

Phone: 92 2127-3438; 92 9439-1290

e-mail: gracasaraiva@fmt.am.gov.br

Received 13 March 2012

Accepted 05 June 2012
Maranhão, Tocantins, Goiás, Distrito Federal, Minas Gerais, São Paulo, Bahia, and Paraná ${ }^{8}$. The species Haemagogus janthinomys is the most common in the wild viral circulation and also has the largest geographical distribution in the country ${ }^{2,4}$. Aedes albopictus is held as a risk for the occurrence of yellow fever, by its susceptibility and ecological adaptability in rural areas, being capable of connecting urban and wild circles in the transmission of this disease 9 .

The presence of vectors provides favorable conditions for yellow fever outbreaks to happen. Besides the low vaccine coverage of the population that lives in endemic areas or otherwise in transition to sylvatic form, the presence of primates considered amplifiers and disseminators of the virus, and the displacement of susceptible people to endemic areas are critical factors in the spread of yellow fever ${ }^{4}$. It is a zoonosis therefore, impossible to eradicate. In Brazil, the disease control is seen as challenging due to the need of high vaccine coverage with consequent reduction of wild cases ${ }^{6}$.

The prevalence of yellow fever and its associated carriers, in municipalities of the State of Amazonas is presented.

A descriptive retrospective study was done from data collection of the following secondary sources: Fundação de Medicina Tropical Doutor Heitor Vieira Dourado (FMT-HVD), Fundação de Vigilância em Saúde (FVS)/Secretaria Estadual da Saúde (SES)-Sistema de Informação de Agravos de Notificação (SINAN).

We have included in this study all cases reported in the period of January 1996 to December 2009 which were confirmed for yellow fever through $\mathrm{M}$ antibody capture enzyme linked immunosorbent (MAC-ELISA) or histopathological laboratory testing. 
The identification of municipalities with the presence of Ae. aegypti and Ae. albopictus was done through the technical reports from FVS/SES and the scientific publications from FMT-HVD ${ }^{10-12}$.

The records of cases, vaccine coverage and vectors, were plotted in tables and figures, using the program ArcGIS( $(\circledR$, whose themed maps help in observing the geographic distribution and spatial analysis.

Between 1996 and 2009, 42 cases of native yellow fever (NYF) were registered. In the evolution of NYF, in these cases, $71.4 \%(30 / 42)$ were fatal, $26.2 \%(11 / 42)$ were cured and $2.4 \%$ (1/42) survived asymptomatically. Five fatalities were reported as having been vaccinated, 17 as not vaccinated and 8 were of unknown vaccinal status.

Of the cured patients, one declared being vaccinated and in 10 cases, patients claimed no knowledge of being vaccinated. Of the cases that were notified as having been vaccinated only one could show a vaccine certificate, however this patient died.

Of the 30 fatalities, $10 \%$ (3/30) were foreigners. The lethality rate in the study's period was $71 \%$ (30/42). From 1996 to 2001 , 28 cases were registered with a fatality rate of $75 \%(21 / 28)$. From 2002 to 2009, after the implementation of the syndrome vigilance, 14 cases were registered with a lethality of $64 \%$ $(9 / 14)$. The drop in the fatality rate during the period after the vigilance was not significant, $\mathrm{p}=0.7171$ (Table 1). From the total, 98\% (41/42) were autochthonous to Amazonas state, native to the 17 municipalities, and in one case imported from Juruti/Pará.

Figure 1 shows the 31 municipalities where cases occurred and the presence of vectors. The rural areas for Manaus and Itacoatiara, registered similar counts of cases, 15\% (6/42) in each municipality. Six of eight municipalities (Manacapuru, Manaus, Rio Preto da Eva, Itacoatiara, Novo Airão and Iranduba) from the metropolitan region of Manaus, concentrated 55\% (23/42) of the cases. Aedes aegypti was found in 27 municipalities of the state, and Aedes albopictus was identified in nine ${ }^{10}$. Among the municipalities registered cases of sylvan yellow fever, 15 with Aedes aegypti infestation, of these three with both Ae. aegypti and Ae. albopictus, Manaus being one of them.

In the year 1996, there was the largest record of cases (15/42 - 36\%), and only one record in between 2000 and 2006 (Table 1). Sixteen different professions where registered, 36\% $(15 / 42)$ being farmers. The male sex had the highest record with $83 \%(35 / 42)$ and $62 \%(26 / 42)$ of the cases were in the age group 20-49 (data not shown).

The accumulated vaccine coverage against yellow fever grew gradually, from $58.9 \%$ in 1996 to a peak during 2000 and 2005, however with a gradual reduction from 2006 (98.1\%),

TABLE 1 - Annual vaccination coverage and accumulated in ten years, cases, deaths and fatality rate of Sylvan yellow fever, registered in the State of Amazonas, Brazil, in the period 1996 and 2009

\begin{tabular}{|c|c|c|c|c|c|}
\hline \multirow[b]{2}{*}{ Years } & \multicolumn{4}{|c|}{ Vaccination coverage (\%) } & \multirow[b]{2}{*}{ Fatality rate $(\%)$} \\
\hline & annual & accumulated & cases & deaths & \\
\hline 1996 & 34.5 & 58.9 & 15 & 13 & 87.0 \\
\hline 1998 & 21.9 & 89.0 & 3 & 1 & 33.0 \\
\hline 1999 & 12.8 & 96.2 & 5 & 4 & 80.0 \\
\hline 2001 & 11.5 & 103.7 & 4 & 3 & 75.0 \\
\hline 1996 to 2001 & & & 28 & 21 & 75.0 \\
\hline 2002 & 8.5 & 111.0 & 6 & 2 & 33.0 \\
\hline 2003 & 8.0 & 113.0 & 0 & 0 & - \\
\hline 2006 & 8.6 & 98.1 & 1 & 1 & 100.0 \\
\hline 2007 & 9.3 & 97.1 & 2 & 2 & 100.0 \\
\hline 2008 & 13.8 & 90.9 & 0 & 0 & - \\
\hline 2009 & 7.3 & 87.0 & 0 & 0 & - \\
\hline 2002 to 2009 & & & 14 & 9 & 64.0 \\
\hline Total & & & 42 & 30 & 71.0 \\
\hline
\end{tabular}

Source: PNI/FVS/SES/SINAN/SVS/MS - Programa Nacional de Imunizações/Fundação de Vigilância em Saúde/Secretaria Estadual da Saúde/Sistema de Informação de Agravos de Notificação/Secretaria de Vigilância em Saúde/Ministério da Saúde. 


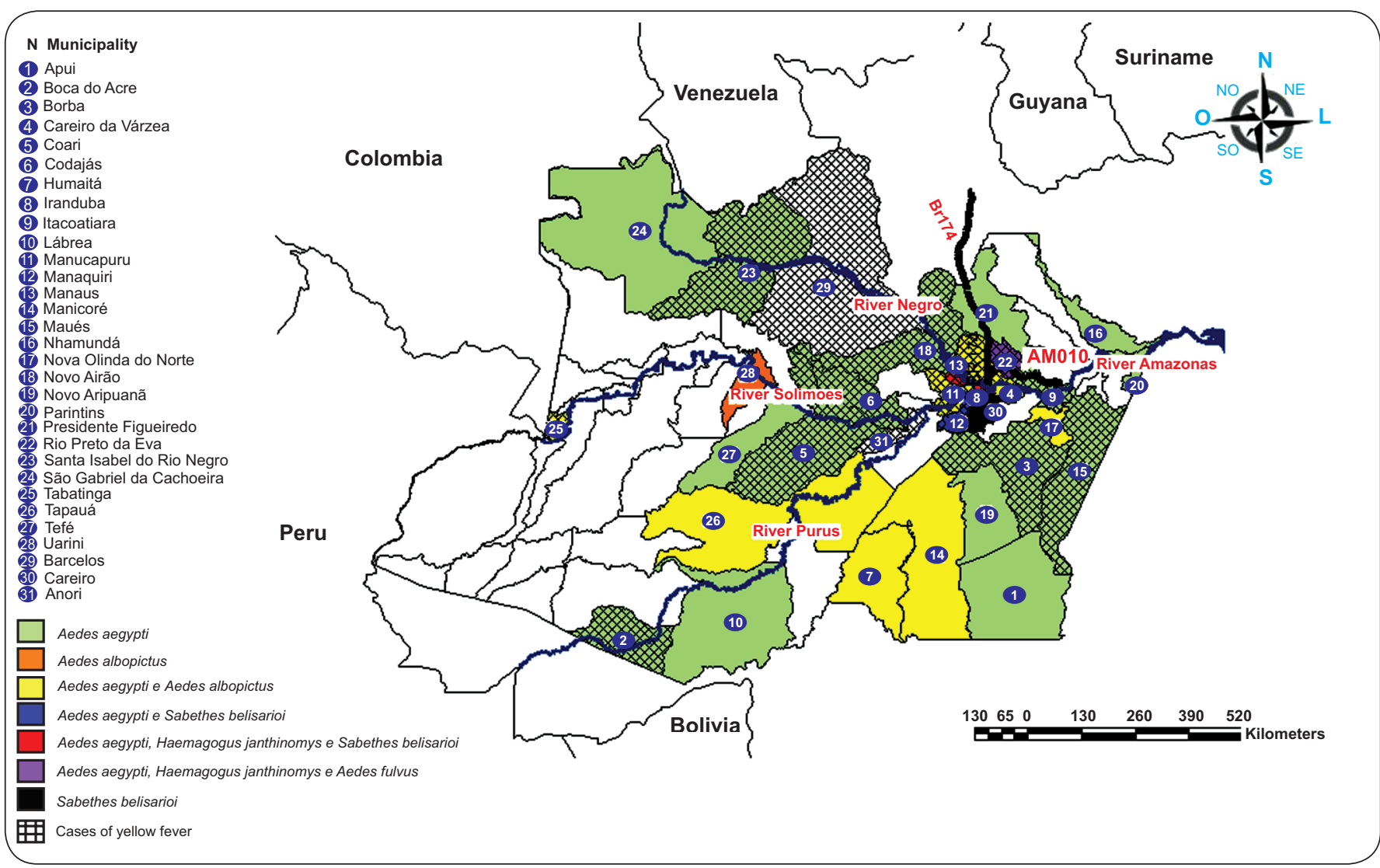

FIGURE 1 - Municipalities of State of Amazonas with the presence of vectors and sylvan yellow fever cases, period 1996-2009.

reaching 87\% in 2009. In the years 1997, 2003, 2008 and 2009 there were no records of yellow fever (Table 1).

The specific diagnosis of patients suspected to have yellow fever is important to the epidemiological surveillance ${ }^{3}$, requiring laboratory surveillance in order to detect the presence of the virus prematurely, alerting the adoption of preventive measures and control ${ }^{4}$

The lethality rate during the periods before and after the implementation of the syndrome surveillance dropped, but was not significant: $p=0.7171$. It could be due to an increase in case detection due implementation of surveillance activities. In the years 2008 and 2009 there were no cases reported; perhaps this was a reflex of the activities implemented by the surveillance or an under-notification of cases due to lack of diagnosis. The death of five vaccinated persons might indicate the possibility of compromising the quality of the vaccine due to cooling.

The male sex contributed to the largest portion of cases in the study, and the age group of 20-49 was the most common. One can note that in Amazonas, the occurrence of cases is related to the most productive age group, and to the male sex probably due to laborrelated activities. Vasconcelos et al. ${ }^{13}$ relates that in the Amazon and in Africa more than $80 \%$ of the cases of yellow fever occur in people of the male sex, aged between 14 and 35, and this preference is due to the largest exposure and not to susceptibility to the virus.

In Amazonas, since 2006, there has been a reduction of the vaccine coverage, while the difficulty in accessing the remote rural areas due to the region's geographic characteristics, vast extension of the state, low population density and need of fluvial transport were present in the past. As an endemic region, it is important to increase the vaccine coverage of the populations and to maintain constant epidemiologicalentomological surveillance ${ }^{14}$, especially for those who move between neighboring municipalities of Manaus, with the presence of Aedes aegypti, and increase the risk of urbanizing the disease ${ }^{11}$.

The study shows that during 2000 and 2005, when vaccine rates were high, 16 cases were registered, and only during 2003 were there no cases of yellow fever. The vaccine has a minimum validity of 10 years and the immunization program needs to stimulate the population constantly to keep the vaccine up to date. The vaccine coverage rarely hits a homogenous distribution and, therefore, does not guarantee the protection needed by all the populations exposed to the risk ${ }^{14,15}$. In spite of the high rates of coverage in the state, there are probably areas of low vaccine coverage as we observe occurrence of cases mainly affecting people from remote areas. Absence of reported cases could be due to lack of clinical suspicion and consequent lack of diagnosis.

In the spatial distribution of the cases, one can note cases in municipalities located primarily in the floodplains of the rivers Solimões and Negro, and on the AM-010 highway. The creation of the Manaus metropolitan region favors the dislocation of people to neighboring municipalities of the capital, through 
the bridge that links Manaus and Iranduba, facilitating the accessibility of the populations, both in the rural and urban areas. Human infection by the yellow fever virus occurs accidentally when people enter the forest for leisure activities, for harvesting of plants/plant extraction ${ }^{11}$, or for agriculture (which comprise $36 \%$ of rural occupation). The fact that there were also cases involving professionals of high degree of education and foreigners, calls attention to the need of health education as well as requesting travelers to present proof of immunization.

The presence of Aedes aegypti and of Aedes albopictus in municipalities in the rural areas and in the capital of Amazonas suggests the dispersion of these vectors and reinforces the need to ensure high vaccine coverage, and maintain continuous and improved epidemiological and entomological vigilance. The record of Aedes aegypti in rural areas of Manaus characterizes the possible dispersion of this species, where the large number of people commuting between the rural and urban areas makes the anthropic transposition of this vector to these areas, enabling outbreaks of focal points of dengue and yellow fever. The presence of Haemagogus janthinomys in forest areas approximately 100 meters from residential areas leaves the population vulnerable to yellow fever that is characterized by the presence of Aedes aegypti intradomiciliary ${ }^{12}$. Entomological surveys revealed the presence of species of Aedes fulvus in Rio Preto da Eva, Haemagogus janthinomys in Iranduba and Rio Preto da Eva, and Haemagogus leucocelaenus in Careiro and Manaquiri ${ }^{11}$. Given the record of Aedes aegypti and Aedes albopictus and due to the accessibility of the populations to areas with the presence of transmitters of native yellow fever, especially in the metropolitan region of Manaus, vaccine coverage is indispensable, as well as georeferencing in the monitoring of these vectors; especially because of macro events such as the 2014 World Cup.

The complex urban areas and the high concentration of population contribute to higher poverty incidence, and as a consequence, the volume of litter and inefficient supply and storage of water in these areas, complicate the elimination or effective control of Aedes aegypti ${ }^{13}$.

The main methods for yellow fever control include: a vaccine coverage above $90 \%$ in all municipalities, a demand for proof of immunization from tourists upon entry, public awareness campaign through all media, which includes information not only on the disease but also for the the need to control Aedes aegypti.

\section{ACKNOWLEDGMENTS}

The authors thank Dr. Giralcina Pessoa Reis Aguiar, and Maria Izabel Nogueira do Nascimento, for their valuable contribution in the study. To Dr. Gerson de Oliveira Penna for his constructive criticism and revision of the manuscript.

\section{CONFLICT OF INTEREST}

The authors declare that there is no conflict of interest.

\section{REFERENCES}

1. Albuquerque BC. Febre amarela. In: Tavares W, Marinho LAC, editors. Rotinas de Diagóstico e Tratamento das Doenças Infecciosas e Parasitárias. São Paulo: Editora Atheneu; 2007. p. 407-408.

2. Saraiva MGG, Amorim RDS, Lopes LDS, Souza MSG, Moura MAS, Fé NF, et al. Febre amarela: arbovirose em vigilância permanente no Amazonas. Rev Soc Bras Med Trop 2006; 39:179.

3. Ministério da Saúde. Secretaria de Vigilância em Saúde. Febre amarela. Aspectos epidemiológicos. Brasília: Ministério da Saúde; 2009. [Cited 2009 July 28]. Available from: http://portal.saúde.gov.br/portal/saude/Gestor/área. cfm?id area $=1498$.

4. Ministério da Saúde. Fundação Nacional de Saúde. Manual de Vigilância Epidemiológica de Febre Amarela. Brasília: Ministério da Saúde; 1999.

5. Tauil PL. Aspesctos críticos do controle da febre amarela no Brasil. Rev Saude Publica 2010; 44:555-558

6. Vasconcelos PFC. Febre amarela; reflexões sobre a doença, as perspectivas para o século XXI e o risco da reurbanização. Rev Bras Epidemiol 2002; 5:244-258.

7. Tauil PL, Santos JB, Moraes MAP. Febre amarela. In: Coura JT, editor. Dinâmica das Doenças Infecciosas e Parasitárias. Rio de Janeiro: Editora Guanabara Koogan; 2005. p. 1755-1765.

8. Silva MA, Zeilhofer P, Santos ES, Ribeiro ALM, Miyazaki RD, Santos MA. Mapeamento de habitats de transmissores da febre amarela silvestre, a partir de técnicas de geoprocessamento, na Região da APM-Manso/MT. Simp Bras Sensoriamento Remoto. Natal: INPE 2009; p.7603-7610.

9. Gomes AC, Bitencourt MD, Natal D, Pinto PLS, Mucci LF, Paula MB, et al. Aedes albopictus em área rural do Brasil e implicações na transmissão de febre amarela silvestre. Rev Saude Publica 1999; 33:95-97.

10. Fé NF, Barbosa MGV, Alecrim WD, Guerra MVF. Registro da ocorrência de Aedes albopictus em área urbana do município de Manaus, Amazonas. Rev Saude Publica 2003; 37:674-675.

11. Fé NF, Barbosa MGV, Fé FAA, Guerra MVF, Alecrim WD. Fauna Culicidea em municípios da zona rural do Estado do Amazonas, com incidência de febre amarela. Rev Soc Bras Med Trop 2003; 36:343-348.

12. Barbosa MGV, Fé NF, Marcião AHR, Silva APT, Monteiro WM, Guerra MVF, et al. Registro de Culicidae de importância epidemiológica na área rural de Manaus, Amazonas. Rev Soc Bras Med Trop 2008; 41:658-663.

13. Vasconcelos PFC. Febre amarela. Rev Soc Bras Med Trop 2003; 32:275-293.

14. Ministério da Saúde. Fundação Nacional de Saúde. Cobertura vacinal contra febre amarela ainda é baixa. Boletim Epidemiológico. Brasília: Ministério da Saúde; 1998.

15. Ministério da Saúde. Secretaria de Vigilância em Saúde. Febre amarela. Guia de Vigilância Epidemiológica. $7^{\text {th }}$ ed Brasília: Ministério da Saúde 2010; Caderno 9:23-41. 